\title{
Kinesiophobia, adherence to treatment, pain and quality of life in fibromyalgia syndrome patients*
}

\author{
Cinesiofobia, adesão ao tratamento, dor e qualidade de vida em indivíduos com síndrome \\ fibromiálgica
}

Giovana Davi Lorente', Lia Fernanda Bocchi De Stefani', Marielza Regina Ismael Martins ${ }^{2}$

${ }^{*}$ Received from the School of Medicine of São José do Rio Preto, São José do Rio Preto, SP, Brazil.

DOI 10.5935/1806-0013.20140020

\section{ABSTRACT}

BACKGROUND AND OBJECTIVES: Fibromyalgia syndrome is characterized by diffuse and chronic musculoskeletal pain, which is difficult to handle and negatively affects patients' quality of life. This study aimed at measuring fear of movement, adherence to treatment and at evaluating health-related quality of life of fibromyalgia syndrome patients.

METHODS: This is a prospective study in convenience sample made up of individuals with fibromyalgia syndrome and treated in a Pain Outpatient Clinic. Tools used were: identification protocol, Fibromyalgia Impact Questionnaire, generic quality of life questionnaire World Health Organization's Quality of Life Instrument, visual analog scale, Tampa Scale for Kinesiophobia and treatment adherence measurement. Participated in the study 65 individuals being 35 with fibromyalgia syndrome called test group and 30 without diagnostic of musculoskeletal and neurological systems diseases called control group.

RESULTS: The test group had predominance of females, mean age of $42.5 \pm 4.3$ years, $53 \%$ were married and mean education was $9 \pm 2.5$ years. Mean pain duration was $3.5 \pm 1.2$ years and mean of two years for fibromyalgia syndrome diagnostic. There has been poorer quality of life, more severe pain and acknowledgment of the importance of physical activities, in spite of referring fear. In addition, adherence to pharmacological treatment was lower than that observed in the control group.

CONCLUSION: Fibromyalgia patients had more severe pain, more fear of movement and poorer quality of life in physical and

1. School of Medicine of São José do Rio Preto, São José do Rio Preto, SP, Brazil. 2. School of Medicine of São José do Rio Preto, Department of Neurological Sciences, São José do Rio Preto, SP, Brazil.

Submitted in November 13, 2013.

Accepted for publication in May 16, 2014.

Conflict of interests: none - Sponsoring sources: Institutional Program of Scientific Initiation Scholarships (PIBIC)/Cnpq/FAMERP.

\section{Correspondence to:}

Marielza R. I. Martins

Av. Brigadeiro Faria Lima, 5416 - Departamento de Ciências Neurológicas

15090-000 São José do Rio Preto, SP, Brasil.

E-mail: marielzamartins@famerp.br

() Sociedade Brasileira para o Estudo da Dor social domains. Adherence to treatment level was medium and there has been decreased functional capacity.

Keywords: Evaluation, Fibromyalgia, Quality of life.

\section{RESUMO}

JUSTIFICATIVA E OBJETIVOS: A síndrome fibromiálgica é caracterizada por dor musculoesquelética difusa e crônica, de difícil manuseio, afetando negativamente a qualidade de vida dos indivíduos. O objetivo deste estudo foi mensurar o medo do movimento, a adesão ao tratamento e avaliar a qualidade de vida relacionada à saúde de indivíduos com síndrome fibromiálgica.

MÉTODOS: Trata-se de um estudo prospectivo em amostra de conveniência composta por indivíduos com síndrome fibromiálgica que realizam atendimento ambulatorial em Clinica da Dor. Os instrumentos utilizados foram: protocolo de identificação, o Questionário de Impacto da Fibromialgia, questionário genérico de qualidade de vida World Health Organization's Quality of Life Instrument, a escala analógica visual, a Escala Tampa de Cinesiofobia e a medida de adesão ao tratamento. Participaram do estudo 65 indivíduos, sendo 35 com síndrome fibromiálgica denominados grupo teste e 30 indivíduos sem diagnóstico de doenças nos sistemas musculoesquelético e neurológico denominado grupo controle.

RESULTADOS: $\mathrm{Na}$ amostra do grupo teste houve predomínio do gênero feminino, média de idade de 42,5 $\pm 4,3$ anos, 53\% casados e média de escolaridade de $9 \pm 2,5$ anos. Foi relatado um tempo médio de dor de 3,5 $\pm 1,2$ anos e média de dois anos para o diagnóstico de síndrome fibromiálgica. Houve pior qualidade de vida, maior intensidade de dor, e reconhecimento da importância da atividade física, apesar de referirem medo. Além disso, constatou-se que a taxa de adesão ao tratamento farmacológico foi inferior ao observado no grupo controle.

CONCLUSÁO: Pacientes fibromiálgicos apresentaram maior intensidade de dor, maior medo de movimento e pior qualidade de vida nos domínios físico e social. $\mathrm{O}$ nível de adesão ao tratamento foi médio e houve decréscimo na capacidade funcional. Descritores: Avaliação, Fibromialgia, Qualidade de vida.

\section{INTRODUCTION}

Fibromyalgia (FM) is a rheumatic, non-inflammatory, chronic syndrome which occurs predominantly in females aged between 40 and 55 years and is characterized by diffuse mus- 
culoskeletal pain and tender points. It is frequently associated to generalized fatigue, sleep disorders, morning stiffness, dyspnea, anxiety and mood changes, which may evolve to depression ${ }^{1}$.

Pain, primary FM characteristic, is different from any other sensory impression because it is characterized not only by the sensory-discriminative dimension lived by the individual, but also by important affective-emotional component, which constitutes pain affective-emotional dimension. Its complexity and subjectivity make difficult its accurate evaluation and justify the use of techniques such as verbal questionnaire, numerical scale, visual analog scale (VAS) and non-verbal indices for its evaluation ${ }^{2}$.

Mood disorders, such as anxiety and depression, are common and important since they negatively influence FM, similarly to what happens with other diseases. For having undetermined origin and uncertain healing, FM brings vulnerability and abandonment feelings. The prevalence of psychological abnormalities, especially depression, is high among such patients, varying from 49 to $80 \%$. Depression may trigger or perpetuate its symptoms, may cause major functional limitations and, consequently, may influence patients' quality of life $^{3}$. It is important to stress, however, that a considerable number of FM patients do not have depression, so that both depression and FM are different clinical conditions ${ }^{4}$.

There is still no defined cause, but there are hints on why people have FM4 . Recent studies show biochemical, metabolic and immunoregulatory abnormalities ${ }^{5}$. Most accepted mechanisms for the pathophysiological understanding of FM is the change in some central pain control mechanism, which could result in neurohormonal dysfunction. This dysfunction could be triggered by viral infection, mental stress or by a physical trauma, among others ${ }^{6}$.

Epidemiological data about its prevalence are variable, according to different studies, depending on the evaluated population and on the methodology applied. Based on international studies ${ }^{7,8}$, the frequency is 1 to $5 \%$ of general population. In medical clinic services, this frequency is around 5\% and in hospitalized patients it is $7.5 \%$. In the rheumatologic clinic, on the other hand, this syndrome is detected in $14 \%$ of patients ${ }^{9}$.

This frequency is progressively increasing since FM is being better understood and diagnostic criteria are improving worldwide ${ }^{8}$. In Brazil, some studies refer a prevalence of approximately $10 \%$ of the general population?

With regard to labor activities, more than $30 \%$ of FM patients are forced to decrease workload or to move to a job with less physical demand to be able to remain employed. In the United States, $15 \%$ of FM patients are disability retirees ${ }^{10}$. In several countries, the recognition of the severity of FM social impact is still unsatisfactory, and the risk of marginalization of such individuals implies an even higher impairment in their quality of life ${ }^{11}$.

So, quality of life evaluation by questionnaires has been recognized as important health scientific knowledge area. This because the concepts of health and quality of life are inter- posed - considered as satisfaction and wellbeing in physical, psychic, socioeconomic and cultural contexts. In the clinical practice, they may identify most influenced contexts by a certain syndrome, evaluate the effectiveness of an intervention and the cost-effectiveness of the treatment ${ }^{12}$.

In light of the above, this study aimed at evaluating quality of life and adherence to treatment of fibromyalgia patients and at observing limitation or fear of movement as well as the presence of pain.

\section{METHODS}

This is a prospective study with convenience sample made up of FM outpatients who were assisted by the Pain Clinic of the Base Hospital Funfarme/Famerp.

Participated in the study 65 patients of both genders, with enough cognitive level to understand procedures and follow given guidance, in addition to agreeing in participating in the study. All patients included in the study have signed the Free and Informed Consent Term.

Patients were allocated to a test group (TG) with diagnosis of FM ( $n=35)$ according to criteria of the American College of Rheumatology, and to a control group (CG) ( $\mathrm{n}=30)$ submitted to referral to the Pain Clinic and without diagnosis of diseases of musculoskeletal and neurologic systems, or disabling complaints in such systems, with recommendations to perform hikes (pelvic pain, vascular, hormonal causes).

Both groups were evaluated by individual and face-to-face interviews using the following tools: Fibromyalgia Impact Questionnaire ${ }^{13}$, World Health Organization's Quality of Life Instrument (Whoqol-bref) ${ }^{14}$, VAS ${ }^{15}$, Tampa Scale for Kinesiophobia (TSK) ${ }^{16}$ and Treatment Adherence Measurement (TAM) questionnaire ${ }^{17}$.

Subjects of all groups were evaluated by $\mathrm{FIQ}^{13}$, which involves 20 questions distributed in 10 items (functional capacity, feeling good, work absences, symptoms interference on work, pain, fatigue, morning stiffness, morning tiredness, anxiety and depression) where nine of the 10 items have the highest score as the worst condition, being exception the item feeling good. Seven of nine items $\left(4^{\text {th }}\right.$ to $10^{\text {th }}$ ) are scored using VAS, that is, between zero and 10 . Functional capacity is evaluated by 10 questions, with answers from zero to 3 , which at the end are added varying from zero to 30. Questions work absences and feeling good are scored in days of the week, originally varying from zero to 5 .

Whoqol-bref quality of life questionnaire ${ }^{14}$ is made up of 26 items representing facets which, in turn, refer to 4 domains: physical, psychological, social relations and environment. Answers to all questions are obtained with a Likert-type scale with five points, where scores may vary from 1 to 5 , in addition to two questions on general quality of life, calculated together to generate a single score independent of domain scores, called overall or general quality of life.

VAS evaluates pain intensity and consists in a straight $10-\mathrm{cm}$ line without numbers, where there is only indication of the left and right extremes as "no pain" and "unbearable pain", 
respectively. The higher the score, the higher the intensity of pain. Patients are oriented to check a point representing pain intensity at interview moment. This scale is an important tool to observe patients' evolution during treatment and even at every visit in a more reliable way, thus allowing treatment efficacy evaluation ${ }^{15}$.

We have used the Brazilian version of the Tampa Scale for Kinesiophobia, one of the most popular tools to evaluate kinesiophobia, that is, excessive, irrational and debilitating fear of movement and physical activity, resulting in feelings of vulnerability to pain or fear of injury recurrence ${ }^{16}$. It is made up of 17 questions addressing pain and symptoms intensity, and scores vary from 1 to 4 , being "totally disagree", "partially disagree", "totally agree" and "partially agree", respectively. To get the final score, scores of questions 4, 8, 12 and 16 have to be inverted. The higher the score, the higher the level of kinesiophobia.

Therapy adherence measurement (TAM), test proposed by Morisky, Green and Levine ${ }^{17}$, evaluates adherence considering all drugs prescribed to the patient, including those indicated to treat other concomitant diseases which may be present. Modified TAM is a questionnaire based on four items and scores vary from zero to 4 , being given 1 point to each negative answer. High adherence to treatment was considered when patients scored 4, medium adherence when patients scored from 2 to 3 and low when patients scored zero to 1 .

A protocol with personal data was also used aiming at collecting information about demographic variables which were only used to characterize samples and assure similarity between groups.

To meet proposed objectives, sociodemographic and clinical data were submitted to descriptive statistical analysis, according to descriptive statistics such as mean, standard deviation, median, extremes and confidence intervals, aiming at supporting quantitative data exploratory analysis. For data analysis, Mann-Whitney and ANOVA tests were used, considering significant 0.05 .

The study was approved by the Research Ethics Committee, School of Medicine of São José do Rio Preto (Opinion $112 / 2010)$.

\section{RESULTS}

Both groups had predominance of females, mean age of $44.5 \pm 3.8$ years, $40 \%$ married and mean education of $8 \pm 2.7$ years. Mean pain duration was reported as $3.5 \pm 1.2$ years and mean of 2 years for clinical diagnosis of fibromyalgia in TG. Table 1 shows sample characterization of both studied groups. With regard to weight and height, it is observed that although with no significant difference between groups, mean body mass index (BMI) is lower for TG (24.7 versus 27.1 for CG; $\mathrm{p}<0.05$ ), which means that FM patients have adequate weight and CG is in the overweight group.

With regard to FM impact evaluated by FIQ, eight out of 10 items had higher score with worse condition, being exception items feeling good, absences and ability to work (Table 2).

Table 1. Sample characterization of studied groups

\begin{tabular}{|c|c|c|c|c|c|}
\hline Variables & Groups & $n$ & Mean \pm SD & $\%$ & $\begin{array}{c}\mathrm{p} \\
\text { value }\end{array}$ \\
\hline Age (years) & $\begin{array}{c}\text { Test } \\
\text { Control }\end{array}$ & $\begin{array}{l}35 \\
30\end{array}$ & $\begin{array}{l}42.5 \pm 4.3 \\
45.5 \pm 2.5\end{array}$ & & 0.06 \\
\hline Gender & $\begin{array}{c}\text { Test } \\
\text { Control }\end{array}$ & $\begin{array}{l}35 \\
30\end{array}$ & & $\begin{array}{l}\text { Female } 93 \\
\text { Female } 80\end{array}$ & 0.06 \\
\hline \multirow[t]{2}{*}{$\begin{array}{l}\text { Marital } \\
\text { status }\end{array}$} & Test & 35 & & $\begin{array}{c}\text { Single } 6.7 \\
\text { Married } 53.3 \\
\text { Divorced } 40\end{array}$ & \\
\hline & Control & 30 & & $\begin{array}{c}\text { Single } 6.7 \\
\text { Married } 58 \\
\text { Divorced } 28.6 \\
\text { Widower } 6.7\end{array}$ & 0.08 \\
\hline $\begin{array}{l}\text { Pain dura- } \\
\text { tion (years) }\end{array}$ & $\begin{array}{c}\text { Test } \\
\text { Control }\end{array}$ & $\begin{array}{l}35 \\
30\end{array}$ & $\begin{array}{l}3.5 \pm 1.2 \\
2.8 \pm 1.8\end{array}$ & & 0.06 \\
\hline $\begin{array}{l}\text { Education } \\
\text { (years) }\end{array}$ & $\begin{array}{c}\text { Test } \\
\text { Control }\end{array}$ & $\begin{array}{l}35 \\
30\end{array}$ & $\begin{array}{l}9 \pm 2.5 \\
8 \pm 3.2\end{array}$ & & 0.06 \\
\hline $\begin{array}{l}\text { Labor } \\
\text { situation }\end{array}$ & Control & 35 & & $\begin{array}{c}\text { Active } 33.3 \\
\text { Unemployed } 0 \\
\text { Retirement } 6.7 \\
\text { Benefit } 60 \\
\text { Active } 37 \\
\text { Unemployed } 11 \\
\text { Rertirement } 17 \\
\text { Benefit } 35\end{array}$ & 0.06 \\
\hline Weight (kg) & $\begin{array}{c}\text { Test } \\
\text { Control }\end{array}$ & $\begin{array}{l}35 \\
30\end{array}$ & $\begin{array}{c}67.14 \pm 9.49 \\
68.5 \pm 8.13\end{array}$ & & 0.58 \\
\hline Height (m) & $\begin{array}{c}\text { Test } \\
\text { Control }\end{array}$ & $\begin{array}{l}35 \\
30\end{array}$ & $\begin{array}{l}1.65 \pm 0.09 \\
1.59 \pm 0.06\end{array}$ & & 0.05 \\
\hline
\end{tabular}

Results obtained by the specific FIQ questionnaire have shown statistically significant difference between CG and TG $(\mathrm{p}<0.05)$ for most items, except for functional capacity and ability to work. All items are shown in table 2 .

Table 3 shows quality of life of studied individuals according to Whoqol-bref.

Quality of life evaluated by the Whoqol-bref questionnaire has shown that, from the five analyzed domains, only physical and social domains have statistically significant differences $(p<0.05)$. Quality of life is poorer for fibromyalgia syndrome patients as compared to CG individuals.

Table 2. Data obtained with the Fibromyalgia Impact Questionnaire in studied groups

\begin{tabular}{lccc}
\hline Variables & $\begin{array}{c}\text { Test group } \\
\text { Mean } \pm \text { SD }\end{array}$ & $\begin{array}{c}\text { Control group } \\
\text { Mean } \pm \text { SD }\end{array}$ & p value \\
\hline Functional capacity & $11.75 \pm 5.73$ & $10.3 \pm 3.00$ & 0.076 \\
Feeling good & $2.35 \pm 1.95$ & $3.38 \pm 0.90$ & $0.048^{*}$ \\
Work absences & $6.04 \pm 2.33$ & $4.85 \pm 2.29$ & $0.035^{*}$ \\
Ability to work & $7.14 \pm 2.05$ & $6.76 \pm 2.00$ & 0.065 \\
Pain & $8.11 \pm 2.67$ & $5.41 \pm 3.19$ & $0.035^{*}$ \\
Fatigue & $8.53 \pm 1.85$ & $5.75 \pm 2.03$ & $0.048^{*}$ \\
Sleep & $7.56 \pm 1.50$ & $6.58 \pm 2.00$ & $0.042^{*}$ \\
Morning stiffness & $8.59 \pm 1.04$ & $6.56 \pm 3.19$ & $0.003^{*}$ \\
Anxiety & $6.59 \pm 3.16$ & $4.95 \pm 2.03$ & $0.022^{*}$ \\
Depression & $6.41 \pm 2.50$ & $5.35 \pm 2.29$ & $0.012^{*}$ \\
\hline *Descriptive significance level of 0.05 of Mann-Whitney non-parametric test.
\end{tabular}


Table 3. Mean of World Health Organization's Quality of Life Instrument domains, among individuals of both groups

\begin{tabular}{lccc}
\hline Domains & $\begin{array}{c}\text { Test group }(\mathrm{n}=35) \\
\text { Mean } \pm \text { SD }\end{array}$ & $\begin{array}{c}\text { Control group }(\mathrm{n}=30) \\
\text { Mean } \pm \text { SD }\end{array}$ & $\mathrm{p}$ value \\
\hline Physical & $49.8 \pm 12.8$ & $64.5 \pm 12.5$ & $0.048^{\star}$ \\
Psychological & $59.6 \pm 20.7$ & $68.6 \pm 18.9$ & 0.119 \\
Social & $54.2 \pm 11.8$ & $65.7 \pm 15.6$ & $0.042^{*}$ \\
Environmental & $63.7 \pm 15.7$ & $73.9 \pm 17.4$ & 0.07 \\
General & $54.5 \pm 21.8$ & $66.7 \pm 18.9$ & 0.627 \\
\hline
\end{tabular}

${ }^{*}$ Descriptive significance level of 0.05 of Mann-Whitney non-parametric test.

With regard to VAS values, TG had higher scores $(7.94>5.5)$ which represents higher pain intensity and higher functional incapacity.

Kinesiophobia evaluated by TSK has measured fear of movement and fear of pain recurrence when moving and had significant difference between groups $(\mathrm{p}=0.035)$. Mean TSK score for TG was $46.93 \pm 10.27$ (varying from 28 to 63) as compared to CG which was 33.4 \pm 7.8 .

Adherence to pharmacological treatment was evaluated with TAM. As shown in table 4, CG adherence was higher as compared to TG.

Table 4. Mean of adherence to pharmacological treatment of both groups

\begin{tabular}{lcc}
\hline Adherence & $\begin{array}{c}\text { Test group }(n=35) \\
\text { Mean }\end{array}$ & $\begin{array}{c}\text { Control group }(n=30) \\
\text { Mean }\end{array}$ \\
\hline High & $20 \%(n=3)$ & $35 \%(n=7)$ \\
Medium & $60 \%(n=9)$ & $50 \%(n=10)$ \\
Low & $20 \%(n=3)$ & $15 \%(n=3)$ \\
\hline
\end{tabular}

\section{DISCUSSION}

Demographic data analysis has shown no statistically significant difference between groups, showing that they were homogeneous with regard to gender (predominantly females) and marital status (married). Pain duration was slightly longer for TG. By evaluating other similar studies, it is observed that mean age of fibromyalgia patients in TG was one of the lowest, since in the study with fibromyalgia patients ${ }^{1,18}$ it was 47.6 and 49.5 years, respectively, while in studies with chronic low back pain (CLBP) patients ${ }^{19,20}$ this mean was 42.0 and 54.2 years, respectively. In addition, TG individuals had mean disease evolution time of approximately four years, much lower than results obtained by CLBP studies ${ }^{17,21}$, which possibly shows the severity of quality of life impairment since such patients look for medical assistance more rapidly.

Although married individuals were predominant in both groups, a much higher divorce rate was observed in TG as compared to CG (40 and 29\%, respectively), which may be consequence of quality of life worsening for those patients, leading to social relations impairment. With regard to level of education there has been no significant differences between studied groups and with regard to occupational losses, it was observed that $60 \%$ of FM patients have received social benefits, while just 35\% of CG have received them, which shows that FM is a disabling disease.
The negative FM impact on quality of life has been reported by several studies ${ }^{3}$, result which was also observed in this study, since all FIQ questionnaire items, where there are statistically significant differences, reveal poorer quality of life in this group of patients, except for the item work absences. This fact may mean that in spite of the low number of patients still professionally active, those who are active are able to better control the disease.

Comparing our results with other studies ${ }^{3,20}$ it was observed that functional capacity and wellbeing for TG are much higher as compared to CG (11.75 vs. 13.30 and $14.93 ; 2.35$ vs. 1.05 and 1.93 , respectively), as well as pain sensation (8.11 vs. 7.75 and 7.77 , respectively), which seems to be a nonsense. It is also noticed that anxiety (6.59 vs. 8.63 and 7.71, respectively) is much lower as compared to previous studies, which could be a possible explanation for better TG functional capacity. However, there are many other factors which could explain such fact, so a deeper study would be needed for any conclusion to be reached.

As to quality of life evaluated by Whoqol-bref, there has been compatibility with results of other studies with chronic pain patients, such as the chronic low back pain study ${ }^{21}$. In comparing the studies, it was observed that four of the analyzed domains have similar scores, and that the Social domain is slightly different ( 54.2 vs. 65.6, respectively). So, one may say that quality of life of FM and CLBP patients is similar and, possibly, lower than population means.

With regard to VAS, a study by Provenza et al..$^{22}$ has shown that patients would refer moderate to severe pain with mean index around 7.32, similar to our study results and also much higher than that observed for CG.

TSK has been widely used to measure fear of movement and fear of injury recurrence. Studies ${ }^{16,21}$ have shown that individuals with high scores have poorer performance in physical tests. TSK values observed in our study are compatible with values of other chronic pain studies, such as the case of $\mathrm{CLBP}^{19}$ (TSK=39.18 \pm 9.46 , varying from 22 to 57 ).

Valim $^{23}$, in his review article, reports that clinical trials using exercises to treat FM have high levels of evidence that supervised aerobic exercises are effective to decrease pain, number of tender points, quality of life and depression, and that these patients seem to need a longer period and more personal effort to adapt to an exercise program, in addition to even getting worse in the first eight weeks. So, short-term trials have not shown improvement in quality of life, while longer programs, with more than 15 weeks, were able to observe improvement in several aspects, including quality of life. Another observed factor was that individuals with more severe pain may be less tolerant to effort and those feeling emotionally worse may feel that they are better supported and cared in a group.

As to adherence to pharmacological treatment, there has been low adherence rate for TG, and even so, much worse than what has been observed by studies with chronic pain patients, which have already observed insufficient adherence to treatment, and that such adherence would not change with time. While in TG, adherence was $20 \%$, this group represented $43 \%$ of such study ${ }^{24}$. 


\section{CONCLUSION}

In our study, fibromyalgia patients had more severe pain, more fear of movement and worse quality of life in physical and social domains. Level of adherence to treatment was medium and there has been decreased functional capacity. So, a multifactorial and multidimensional approach is critical for the therapeutic success of such patients.

\section{REFERENCES}

1. Santos AM, Assumpçăo A, Matsutani LA, Pereira CA, Lage LV, Marques AP. Depressáo e qualidade de vida em pacientes com fibromialgia. Rev Bras Fisioter. 2006;10(3):317-24

2. Ferreira EA, Marques AP, Matsutani LA, Vasconcellos EG, Mendonça LL. Avaliação da dor e estresse em pacientes com fibromialgia. Rev Bras Reumatol. 2002;42(2):104-10.

3. Berber JD, Kupek E, Berber SC. Prevalência de depressão e sua relação com a qualidade de vida em pacientes com síndrome da fibromialgia. Rev Bras Reumatol. 2005; 45(2):47-54.

4. Fibromialgia - Cartilha para pacientes. Sociedade Brasileira de Reumatologia. 2011

5. Sánchez MA. Fibromialgia. Colomb Med. 2005;36(4):287-91.

6. Helfenstein M, Feldman D. Síndrome da fibromialgia: características clínicas e associaçôes com outras síndromes disfuncionais. Rev Bras Reumatol. 2002;42(1):8-14.

7. Vallejo M, Martínez-Martínez LA, Grijalva-Quijada S, Olguín-Ruvalcaba HM, Salas E, Hermosillo AG, et al. Prevalence of fibromyalgia in vasovagal syncope. J Clin Rheumatol. $2013 ; 19(3): 111-4$

8. Wolfe F, Brähler E, Hinz A, Häuser W. Fibromyalgia prevalence, somatic symptom reporting, and the dimensionality of polysymptomatic distress: results from a survey of the general population. Arthritis Care Res . 2013;65(5):777-85.

9. Rocha ce, Martins MR, Foss MH, Santos Junior R, Dias LC, Forni JE, et al. Melhora da qualidade de vida de pacientes com dor neuropática utilizando de monitorização ambulatorial contínua. Rev Dor. 2011;12(4):291-6.
10. International Association for the Study of Pain (IASP). Pain - Clinical Updates. Volume XVI, Issue 4. June 2008. [editorial]

11. Van Abbema R, Van Wilgen CP, Van Der Schans CP, Van Ittersum MW. Patients with more severe symptoms benefit the most from an intensive multimodal programme in patients with fibromyalgia. Disabil Rehabil. 2011;33(9):743-50.

12. Martins MR, Polvero LO, Rocha CE, Foss MH, Santos Junior RD. Uso de questionários para avaliar a multidimensionalidade e a qualidade de vida do fibromiálgico. Rev Bras Reumatol. 2012;52(1):21-6.

13. Marques AP, Santos AM, Assumpção A, Matsutani LA, Lage LV, Pereira CA. Validaçáo da versão brasileira do Fibromyalgia Impact Questionnaire (FIQ). Rev Bras Reumatol. 2006;46(1):24-31.

14. Fleck MP, Louzada S, Xavier M, Chachamovich E, Vieira G, Santos L, et al. [Application of the Portuguese version of the instrument for the assessment of quality of life of the World Health Organization (WHOQOL-100)]. Rev Saude Publica. 1999;33(2):198-205. Portuguese.

15. Pimenta CA. Escalas de avaliaçấo de dor. In: Teixeira MD. (editor). Dor conceitos gerais. São Paulo: Limay; 1994. 46-56p.

16. Siqueira FB, Teixeira-Salmela LF, Magalhães LD. Escala de tampa de cinesiofobia-brasil. Acta Ortop Bras. 2007:15(1):19-24.

17. Morisky DE, Green W, Levine DM. Concurrent and predictive validity of a self-reported measure of medication adherence. Med Care. 1986;24(1):67-74.

18. Case Management Society of America. Guidelines from the Case Management Society of America for improving patient adherence to medication therapies. CMGA-1, 2004.

19. Pagano T, Matsutani LA, Ferreira EA, Marques AP, Pereira CA. Assessment of anxiety and quality of life in fibromyalgia patients. Sao Paulo Med J. 2004;122(6):252-8.

20. Stefane T, Santos, AM, Marinovic A, Hortense P. Dor lombar crônica: intensidade de dor, incapacidade e qualidade de vida. Acta Paul Enferm. 2013;26(1):14-20.

21. Heuch I, Foss IS Acute low back usually resolves quickly but persistent low back pain often persists. J Physiother. 2013;59(2):127.

22. Provenza JR, Pollak DF, Martinez JE, Paiva ES, Helfenstein M, Heymann R, et al Fibromialgia. Rev Bras Reumatol. 2004;44(6):443-9.

23. Valim V. Benefícios dos exercícios físicos na fibromialgia. Rev Bras Reumatol. 2006;46(1):49-55.

24. Kurita GP, Pimenta CA. Adesão ao tratamento da dor crônica. Arq Neuropsiquiatr 2003;61(2-B):416-25. 